\title{
Erratum to: Extracting drug-enzyme relation from literature as evidence for drug drug interaction
}

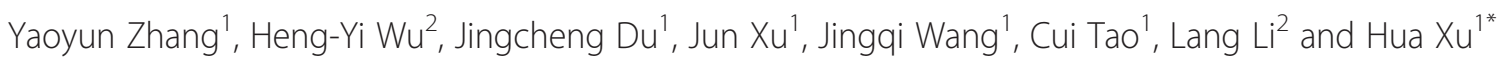

Following the publication of the original article [1] it was brought to our attention that an important acknowledgement from co-author Jingcheng $\mathrm{Du}$ was missing from the manuscript. The authors would like to apologise for this oversight and now take the opportunity to gratefully acknowledge the support from the UTHealth Innovation for Cancer Prevention Research Training Program Pre-doctoral Fellowship (Cancer Prevention and Research Institute of Texas grant \# RP140103).

\section{Author details}

${ }^{1}$ School of Biomedical Informatics, University of Texas Health Science Center at Houston, Houston, TX, USA. ${ }^{2}$ School of Medicine, Indiana University,

Indianapolis, IN, USA.

Received: 5 April 2016 Accepted: 5 April 2016

Published online: 19 April 2016

\section{Reference}

1. Zhang $Y$ et al. Extracting drug-enzyme relation from literature as evidence for drug drug interaction. J Biomed Semantics. 2016;7:11.

\footnotetext{
* Correspondence: hua.xu@uth.tmc.edu

${ }^{1}$ School of Biomedical Informatics, University of Texas Health Science Center at Houston, Houston, TX, USA

Full list of author information is available at the end of the article
}

Submit your next manuscript to BioMed Central and we will help you at every step:

- We accept pre-submission inquiries

- Our selector tool helps you to find the most relevant journal

- We provide round the clock customer support

- Convenient online submission

- Thorough peer review

- Inclusion in PubMed and all major indexing services

- Maximum visibility for your research

Submit your manuscript at www.biomedcentral.com/submit
() Biomed Central 